\title{
Party smart card
}

\author{
A transfer of allegiance.
}

\section{Barrington J. Bayley}

Pig farmer Igor scratched his porky belly under his smock on emerging from the sty after tipping swill into the trough. Behind him were satisfied grunts from feeding snouts.

As a member of the Smallholders' Alliance Party, he felt supremely confident to be treading the muck of the farmyard. The Party would make life better for all pig farmers...but what was this? Sacha, his brat of a nephew foisted on him after the murder of his family, had fished his damned books out of the slurry bin where Igor had thrown them, and was wiping the bemerded covers. Books! No use to a pig farmer. Igor hurried to cuffhim. The ten-year-old went sprawling in the filth, the volumes flopping from his hands. Scarcely able to read, Igor did not take in the titles: Weapons of the Great Patriotic War and Nuclear Power: What it Means. Sacha stared up at him with hard, steady eyes. Igor hated the boy. No matter how much you thrashed him you couldn't break his spirit.

"Get to the kitchen. Mash more swill."

Sacha stood up, not retrieving his books. He knew it would only enrage Igor the more. Unlike Igor, he lacked a Party transfer on his brow. Such wasn't for the likes of him.

He trudged off. Something else distracted Igor. Three horsemen were descending the eastern slope. He stood nervously as they trotted into the farmyard. They were shabbily dressed, their mounts ungroomed, but the coloured transfers on their brows made Igor afraid. They were not crude and smudged like his, but well defined: a blue circle and a white bar against a red background.

The leader spoke down at him. ${ }^{\alpha} \mathrm{I}$ am hetman of the Sovrina Party. We are here to enrol you."

"I am loyal to the Smallholders' Alliance Party! I Igor shouted. He tried to run, but another Sovrina Party man had dismounted and now seized him. "Huh!" the hetman snorted. "Just look at that transfer. Blurred and wishy-washy. Brewed in a cowshed.

There was something in his hand. It was a party decal card. He leaned down, slapping it on Igor's brow. With a cold sensation the card's thin transfer film attached itself. It was stronger than the Smallholders' Alliance. Already the weaker transfer was obliterated. New psychoactive opin-

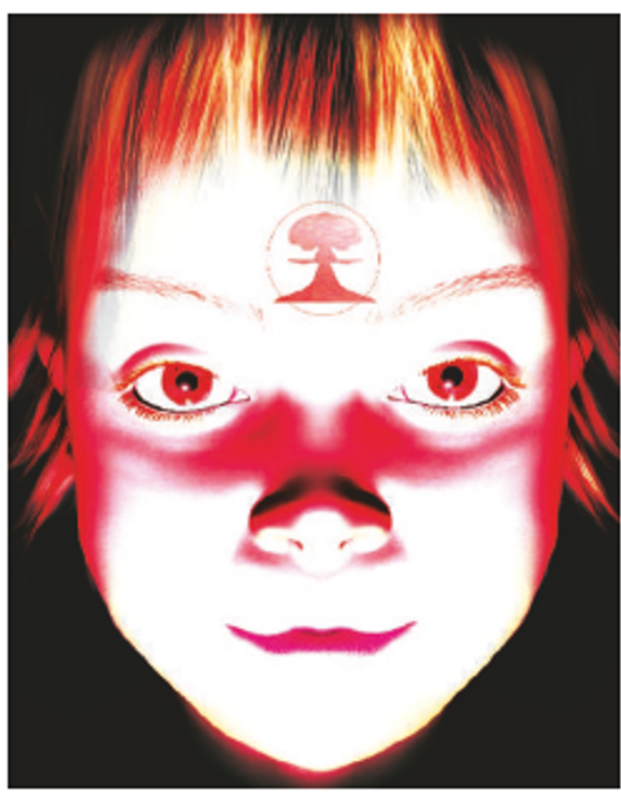

His forehead itched. He wiped it with $\zeta$ his sleeve. His temporary transfer smeared off (only he among his troop had a temporary one). It revealed a brilliant, flashing mushroom cloud, the strongest psychotransfer of all, one which could not be expunged and which overrode all others. The party card of the Warmaster, prophesied to appear one day and take charge of the Forced Reconstruction Party, according to the élite cabal Ivorschenko belonged to, restoring everything. Tanks! Submarines! Warplanes! Atomic energy!

Even ammunition for his ancient Kalashnikov.

Ivorschenko flinched as a crossbow bolt was put through the head of the pig farmer. For some reason his transfer wasn't taking effect properly. Only then did Ivorschenko notice that a ion-bearing vector molecules migrated through Igor's skin, his skull, his meninges, and flooded his brain. In a few exhilarating moments all his political views were rearranged. Sovrina! A country that would rule for hundreds of kilometres around! His country!

Then a bugle-call made the hetman look round. "Damn!" he muttered. "They've found us."

A second troop was cantering down the slope, this one ten strong. With whoops of triumph they circled round those in the farmyard then reined in, horses stamping. The leader was easy to pick out: moustachioed, wearing a sheepskin jacket and an Astrakhan hat and brandishing a Kalashnikow, which made Igor's eyes bulge. Their brow transfers were spectacular, displaying a collage of a tank, a warplane and a missile.

"Get down," the leader ordered his men.

Ivan Ivorschenko, self-styled Servant of the Great, lounged in his saddle, watching his men slap Forced Reconstruction Party decals on the prisoners. It was ironic that the collapse of the world's population, due to disease and famine, while emptying the cities and bringing large-scale organization to a calamitous end, had allowed small technology to come into its own. Psychoactive decals needed no factories. They could be made in a kitchen, if you knew how. The world was a morass, a welter of tiny parties. Transfer after transfer must have been forced on hapless peasants like the pig farmer. Those who made the strongest decals would prevail eventually, as humanity slowly pulled itself together. small boy had crept from the miserable cottage and was picking up books from the evil-smelling mud.

"What have you got there?"

The boy approached, allowing Ivorschenko to read the titles. Ivorschenko smiled.

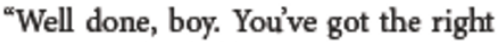
idea. Here, take this."

He reached into his saddlebag and handed down a Party booklet blotchily printed on coarse paper. The boy's eyes gleamed on seeing the title: How to Rule the World with Ballistic Missiles.

"What's your name?"

"Sacha, sir."

"And him?" Ivorschenko nodded to the smock-clad corpse lying in the muck.

"He was nobetter than the pigs he kept."

"Then the Party was right to reject him."

There was something about the lad. His gaze was level and unafraid. Ivorschenko reached down and pulled him up on his horse. "Let me finish your education."

He didn't know why he did it. Warmaster decals were rare, and he only possessed one. He took it from his pocket and applied it to Sacha's brow. The boy's eyes shone with sudden transformation.

${ }^{\alpha}$ Ride on! ${ }^{\circ}$ he commanded in a piping voice.

Ivorschenko spurred his horse. He had found him!

The Warmaster!

Barrington J. Bayley's science-fiction production spans half a century. The Soul oft the Robot, The Zen Gun (novels) and Gnostic Endings (a story collection) are typical of his work. 